\title{
Gap Analysis on the Competency of Indonesian Tourism Workers in the ASEAN Economic Community
}

\author{
George Martin Sirait \\ Department of Business Administration \\ Atma Jaya Catholic University of Indonesia \\ Jakarta, Indonesia \\ martin.sirait@atmajaya.ac.id
}

\author{
Nyoman Agus P. Pinia \\ Department of Hospitality \\ Atma Jaya Catholic University of Indonesia \\ Jakarta, Indonesia \\ nyoman.pinia@atmajaya.ac.id
}

Abstract- Tourism is one of eight professions that are prioritized to be integrated in the framework of ASEAN Economic Community. Among the prioritized professions, tourism has led in producing detail arrangements of mutual recognition agreement in the sector, including by setting ASEAN Common Competence Standards for Tourism Professionals (ACCSTP) and Common ASEAN Tourism Curriculum (CATC). It means the mobility of tourism workers or professionals in the regional labour market may be realized faster than other professions. However, there is a considerable concern over the quality of Indonesian human resources in tourism that may hinder benefits offered by the opening of the regional labour market. This paper investigates potential gaps between standard competencies of AEC and competencies of Indonesian tourism workers. Through a survey conducted in Greater Jakarta, this study found no significant gap between the two. This paper argues the low gap may be due to majority respondents are trained in schools of tourism located in urban, big cities which enjoy quality curriculum and trainers. Nevertheless, the paper encourages a full adoption of regional qualification standards to guarantee the skills recognition of the Indonesian tourism workers in the region.

Keywords-ASEAN Economic Community; tourism workers; labour mobility; competency; gap analysis

\section{INTRODUCTION (HEADING 1)}

The ten ASEAN members have agreed to formally implement ASEAN Economic Community (AEC) starting from the very beginning of 2015. As the AEC Blueprint states that the economic integration of the region consists of four pillars, namely, (1) a single market and production base, (2) a highly competitive economic region, (3) a region of equitable economic development, and (4) a region fully integrated into the global economy (ASEAN, 2008). Under the first pillar the members agree to facilitate the free flow of goods, free flow of services, free flow of investment, freer flow of capital, and free flow of skilled labour. Amongst other objectives, the free mobility of skilled labour is aimed at facilitating the free flow of services and developing core competencies and qualifications for jobs. The Despite criticism of excluding an arrangement of low skilled labour which have already characterized labour mobility across countries within the region (ILO and $\mathrm{ADB}, 2014$ ), the inclusion of labour in the economic agreement marks a new history of the ASEAN.

The ASEAN country members have selected eight professions that would be prioritized in the free mobility of skilled labour scheme. The professions are engineering services, nursing services, architecture, medical practice, dental practice, accountancy, land surveying, and tourism (Capannelli, 2013). The ASEAN members have set up mutual recognition arrangements (MRAs) for most of these professions. The members also seek to develop ASEAN's institutional framework for skills recognition. Amongst the eight prioritized professions, tourism has stepped faster by formulating Roadmap for Integration of Tourism Sector (RITS). The roadmap underlines the importance to standardize curriculum in tourism schools and minimum competencies in the industry.

Up to now, tourism has had ASEAN Common Competency Standards for Tourism Professionals (ACCSTP) that defines minimum competency requirements of 32 job titles in hotel and travel services (Laksaguna, 2013). The job titles include 23 titles in hotel ( 5 in front office, 6 in housekeeping, 7 in food production and 5 in food and beverage services) while the rest covers job titles in travel services ( 4 in travel agency and 5 in tour operation). A worker in food and beverage, for instance, should incorporate 38 competency units: 5 core competencies (such as skills to maintain hospitality industry knowledge and to implement occupational health \& safety procedures); 10 generic competencies (such as, skills to communicate effectively on the telephone and speak English at a basic operational level); and 23 functional competencies (such as skills to manage and monitor operational budget) (Laksaguna, 2013). 
As the development of regional institutional framework is being advanced, there is a considerable concern about Indonesia human resources in tourism industry. The Association of Indonesia Tourism Higher Education (Himpunan Pendidikan Tinggi Pariwisata Indonesia/Hildiktipari) indicated that despite a growing Indonesia's tourism industry, the quality of hospitality services remain low as a consequence of the limited skills owned by Indonesian tourism workers or professionals (Lemy, 2015). One of them is relative to skills in language or communicating in English. This constraint is predicted to potentially hinder Indonesians from reaping the most benefit offered by the integration of tourism labour market. As a response to this constraint, Indonesia sets national movement to develop competency-based human resources in tourism. Nevertheless, up to date most of Indonesia's schools of tourism have not yet adopted fully the ASEAN qualification standard frameworks in tourism. This situation raises concern about potential gaps existing in the regional standards and the competencies of Indonesian tourism workers.

This paper investigates the potential gap between competency standard set in AEC and the existing competencies of Indonesian workers in tourism industry. It also seeks factors responsible to creating or not creating such gap. Finally, it explores some necessary ways to fill the gap so Indonesian hospitality workers are able to take benefit most from the integration of tourism labour market.

\section{THEORETICAL FRAMEWORK}

Skills or competency are essentially individual qualifications but an aggregate individual skills is increasingly related to competitive advantage of a nation (Hall and Soskice, 2001). The lack of needed skills is one of determining factors to create unemployment (World Bank, 2010). Skills formation can be made through a couple of education systems: first is through formal and general education and then depends on particular corporations to shape specific skills. The second is through vocational training institutions that are strongly related to specific sector or industry. In the latter system state usually develops a formal mechanism to certify specific skills and sets nation-wide recognition of different qualifications. In the context of advanced countries, the first system is usually found in liberal market economies, such as USA or UK, while the second one is adopted coordinated market economies, such as, Germany and Japan (Thelen, 2009).

Skills can be broadly disaggregated into three main categories (Gropello, Kruse, Tandon, 2011): academic skills these skills are associated with subject areas (math, literacy, English) and are generally measured thorugh standardized scores.

Generic (or life) skills. This broader set of skills is transferable across jobs generally. It includes thingking skills 9critical and creative thinking, problem solving, and so forth); behavioral skills 9typically communication, organization, teamwork, and leadership skills); and computing skills.
Technical skills. These skills are associated with a profession and are generally a mix of the spesific knowledge and skills to perform a job.

In indonesia, skills most in demand are in the service sector and export-oriented sector (Gropello, Kruse, Tandon, 2011). Subtantively, gaps (skill gaps), can be assessed in various ways (Gropello, Kruse, Tandon, 2011). One is based on gaps in relation to employers' (and employees') expectations (Gropello, Kruse, Tandon, 2011). The other, when avaliable, is based on gaps in relation to an international average or an average in higher-income countries (Gropello, Kruse, Tandon, 2011). The first definition is based on a demand-side approach and is often the only way to measure gaps in higher-level skills (Gropello, Kruse, Tandon, 2011). The second definition is based on a supply-side approach (standardized international testing) and is still avaliable only up to lower-secondary education and, therefore, only for more basic skills (mostly, though not solely, academic skills) (Gropello, Kruse, Tandon, 2011).

Indonesia's education system tends to be similar to the first system above. Skill formation depends largely on general education rather than specific vocational institutions. There are some industry-specific vocational schools in the country but competencies gained by their graduates have not yet systematically certified and recognized nation-wide by relevant industry. The absence of this national system may be detrimental to Indonesian labour force. Standardization of specific competencies is needed to be recognized nationally and regionally. To do so, three components are necessary in place, namely competency qualification framework, educational institutions having standardized curriculum, and associations of particular professions that recognize the competencies (Abdurahman, 2015).

Competency requires the application of three aspects, namely, specified knowledge, skills and attitudes relevant to effective participation, consistently over time and in the workplace environment (ASEAN, 2012). Knowledge identifies what a person needs to know to perform the work in an informed and effective manner. Skills describe the application of knowledge to situations where understanding is converted into a workplace outcome. Attitude describes the founding reasons behind the need for certain knowledge or why skills are performed in a specified manner. A competent person should incorporate these three aspects.

Mutual Recognition Arrangement (MRA) on Tourism Professional has set a standardization of tourism competencies in ASEAN region. The MRA serves as one of regional facilitating systems to allow the participating nations to recognize competencies from other nationals. The MRA has detailed core, generic, and functional competencies of different job titles in the tourism. Using the standard competencies of tourism workers that have been set in the $\mathrm{AEC}$, this paper would like to investigate the possible gaps 
with competencies owned by Indonesian tourism workers, as illustrated by figure below.

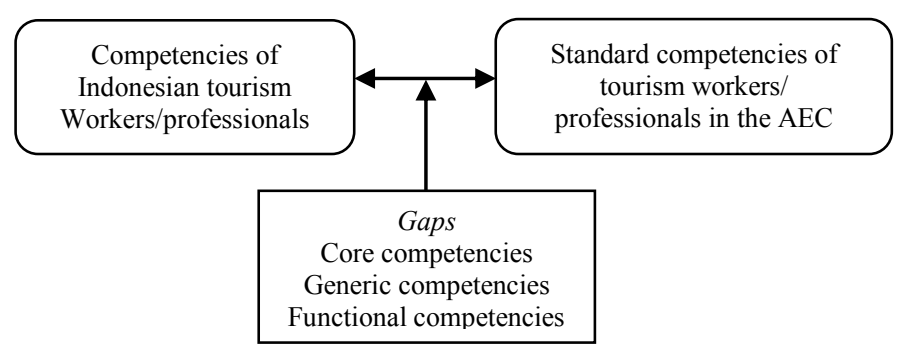

Figure 1 - Analytical framework

\section{METHODOLOGY}

This study combines quantitative and qualitative approaches. Primary data was collected through a survey and in-depth interviews. A total of 200 samples from six participated diploma level schools of tourism in Greater Jakarta was selected through purposive sampling method. The criteria used to guide selection of sample are tourism students who are in the final year of diploma 3 or 4 and had undertaken internships. These criteria represent both educational and practical aspects of the sample to which this paper refers to tourism workers'. They are considered new entrants to tourism labour market. In addition to survey, the study conducted in-depth interviews with tourism educators/trainers, association of tourism higher education and an expert specializing in the standardization of tourism competencies in the AEC context. These semi-structured interviews were intended to understand factors responsible to creating the possible gaps and explore options to fill the gaps. Data collection was carried out from November 2015 to March 2016.

The study investigates competencies of hotel workers at supervisory levels, particularly, in front office and housekeeping divisions. A Handbook of ASEAN MRA on Tourism Professionals defines diploma in front office (supervision and administration) as being -designed to reflect the role of a supervisor or assistant manager in the Secondary Labour Division of Front Office" with job title Front Office Supervisor (ASEAN, 2013, 70); while diploma in housekeeping (supervision and administration) is designed to reflect the role of a supervisor or assistant manager in the Secondary Labour Division of Housekeeping" (ASEAN, 2013, 71). The job titles include laundry manager, head of housekeeper, assistant executive housekeeper, assistant housekeeper administrator. This study compares core, generic and functional competencies of both supervisor positions as defined by the ACCSTP and the competencies of the surveyed samples.
To compare the competencies, respondents did selfassessment in a list of ACCSTP standard competencies consisting of core competencies, generic competencies and functional competencies of each two job titles. The respondents gave scores to their existing competencies from 1 to 10 scales in which 1 represents unskilled" measure while 10 refers to highly skilled' one. Overall, the respondents" answers were then measured in the competency ranking scale below (Table 1) to analyze the gaps.

TABLE 1 - COMPETENCY RANKING SCALE

\begin{tabular}{|c|c|}
\hline $1.0-2.8$ & Unskilled \\
\hline $2.9-4.6$ & Low skilled \\
\hline $4.7-6.4$ & Moderately skilled \\
\hline $6.5-8.2$ & Skilled \\
\hline $8.3-10.0$ & Highly skilled \\
\hline
\end{tabular}

\section{FINDINGS AND DISCUSSIONS}

Gender composition in this study is quite evenly distributed in which female made up $54 \%$ of total respondents while proportion of male was $46 \%$. Regarding educational level, majority of respondents were final year students in Diploma 4 (65\%) while the rest was those in Diploma 3 (see, Figure 2a). The vast majority of them were majoring in hotel. Almost all of them just undertook an internship in the last a couple of years, namely in 2015 (71\%) and 2014 (24\%). The internships were conducted in particular hotels for up to six months. The placement of internships varies from F\&B (47\%), pastry $(22 \%)$, front office (17\%) and housekeeping (10\%). In addition, a few of them did internships in back office jobs, such as accounting, purchasing or human resource (Figure 2b). This characteristic indicates that the respondents not only have incorporated theoretical requirements but also practical experience that shapes their skills.

Respondents' Educational Level 


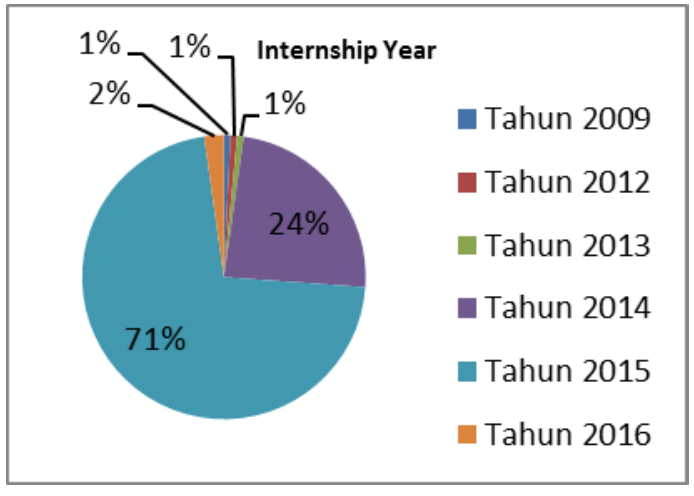

Figure 2 - Respondents` educational level and Internship year

Respondents" self-assessment on their core competencies shows that little gap exists between the ASEAN tourism competency standard and the respondents" perceived competencies. Averagely, the total score of the five components is 8.0 , meaning they fall in upper skilled category. Of the five components, the highest scores lie on skills to comply with workplace hygiene procedures (8.28) and to maintain hospitality industry knowledge (8.22). This can be particularly understood as all respondents are in the final year of their training or fresh graduates so their knowledge about the industry is still updated. Meanwhile the lowest score in the core competency category is located in skill to work effectively with colleagues and customers (7.89).

\section{TABLE 2 - SCORE OF CORE COMPETENCIES}

\begin{tabular}{|c|l|c|c|}
\hline $\begin{array}{c}\text { Question } \\
\text { No }\end{array}$ & \multicolumn{1}{|c|}{$\begin{array}{c}\text { Core } \\
\text { Competencies }\end{array}$} & $\begin{array}{c}\text { Average } \\
\text { score }\end{array}$ & $\begin{array}{c}\text { Competency } \\
\text { Level }\end{array}$ \\
\hline 1 & $\begin{array}{l}\text { Work effectively with } \\
\text { colleagues and customers }\end{array}$ & 7.89 & Skilled \\
\hline 2 & $\begin{array}{l}\text { Work in a socially diverse } \\
\text { environment }\end{array}$ & 7.95 & Skilled \\
\hline 3 & $\begin{array}{l}\text { Implement occupational } \\
\text { health \& safety procedures }\end{array}$ & 7.90 & Skilled \\
\hline 4 & $\begin{array}{l}\text { Comply with workplace } \\
\text { hygiene procedures }\end{array}$ & 8.28 & Skilled \\
\hline 5 & $\begin{array}{l}\text { Maintain hospitality } \\
\text { industry knowledge }\end{array}$ & 8.22 & Skilled \\
\hline
\end{tabular}

Figure 3 depicts the distribution of the five core components that are essential for those working as supervisors in front office and housekeeping. It seems respondents are more confident with their technical skills of the core competencies (such as, complying with workplace hygiene procedures) than their social skills (such as, working effectively with colleagues and customers and working in a socially diverse environment. This indicates the necessity to take these social aspects into account in the formation of the Indonesian tourism workers or professionals.

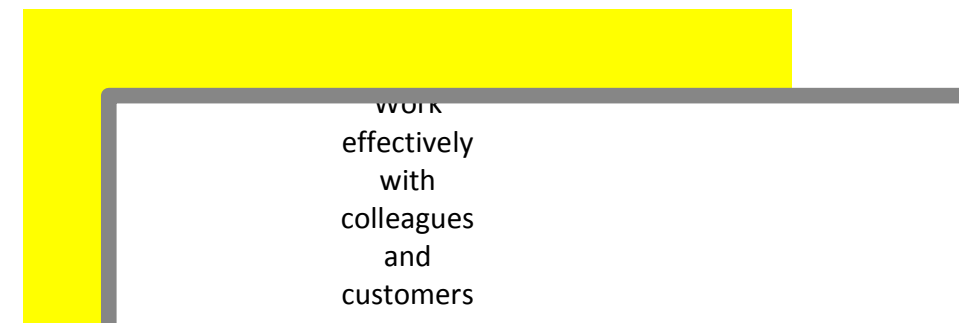

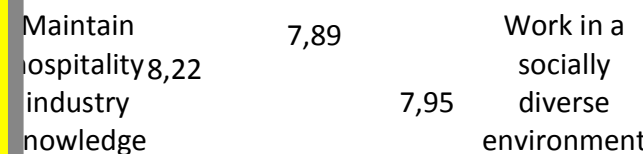

\section{Comply with \\ workplace \\ hygiene 8,28 procedures}

\author{
7,90 Implement \\ health \& \\ safety \\ procedures
}

igure 3 - The distribution level of core competencies

Regarding generic competencies, by and large the respondents perceived that they are skilled in the eight selected competencies. Averagely, the total score of the nine components is 7.7, meaning they are lower than that of core competencies but remain falling in middle skilled category. Of the nine components, the highest scores lie on skills to use common business tools and technology (7.90) and to promote hospitality products and services (average 7.75). Meanwhile the lowest scores in the category sit in skills to perform basic clerical procedures (average 7.51) and manage \& resolve conflicts situations (7.53).

Table 3 - SCORES OF GENERIC COMPETENCIES

\begin{tabular}{|c|l|c|c|}
\hline $\begin{array}{c}\text { Question } \\
\text { No }\end{array}$ & \multicolumn{1}{|c|}{$\begin{array}{c}\text { Generic } \\
\text { Competencies }\end{array}$} & $\begin{array}{c}\text { Average } \\
\text { Score }\end{array}$ & $\begin{array}{c}\text { Competency } \\
\text { Level }\end{array}$ \\
\hline 6 & $\begin{array}{l}\text { Communicate effectively } \\
\text { on the telephone }\end{array}$ & 7.62 & Skilled \\
\hline 7 & $\begin{array}{l}\text { Promote hospitality } \\
\text { products \& services }\end{array}$ & 7.75 & Skilled \\
\hline 8 & $\begin{array}{l}\text { Perform basic clerical } \\
\text { procedures }\end{array}$ & 7.51 & Skilled \\
\hline 9 & $\begin{array}{l}\text { Use common business } \\
\text { tools \& technology }\end{array}$ & 7.90 & Skilled \\
\hline 10 & $\begin{array}{l}\text { Access \& retrieve } \\
\text { computer-based data }\end{array}$ & 7.71 & Skilled \\
\hline 11 & $\begin{array}{l}\text { Develop \& update local } \\
\text { knowledge }\end{array}$ & 7.64 & Skilled \\
\hline 12 & $\begin{array}{l}\text { Manage \& resolve } \\
\text { conflicts situations }\end{array}$ & 7.53 & Skilled \\
\hline
\end{tabular}




\begin{tabular}{|c|l|c|c|}
13 & $\begin{array}{l}\text { Speak English at a basic } \\
\text { operational level }\end{array}$ & 7.70 & Skilled \\
\hline 14 & $\begin{array}{l}\text { Perform basic First Aid } \\
\text { procedures }\end{array}$ & 7.57 & Skilled \\
\hline
\end{tabular}

Looking at the distribution of the generic competencies, like in the core ones, the respondents seem more confident in their technical skills (such as, using common business tools and technology, promoting hospitality products and services and accessing and retrieving computer-based data) but less confident with their social skills, such as, managing and resolving conflicts situations as well as developing and updating local knowledge). Surprisingly, the respondents found less confident with their skill to perform basic clerical procedures. However, unlike a shared perception on the weakness of the Indonesian tourism workers, respondents of this survey are virtually confident with their skill in speaking English at a basic operational level.

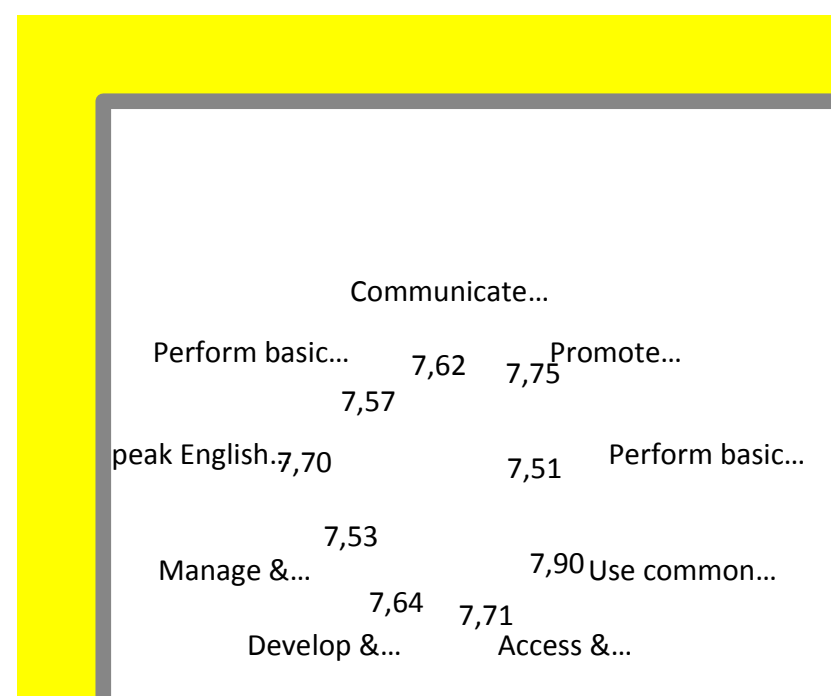

Figure 4 - The distribution level of generic competencies

As mentioned above, the survey particularly investigates the functional competencies of tourism workers at supervisory level. Despite having not yet arrived at this level, the respondents were asked to perceive their capabilities if they are in charge in the positions based on their existing training and education. Those who consider themselves doing roles of front office supervisors, perceive that they have skilled level competencies. Averagely, the total score of the seven selected functional components is 7.5 , meaning they fall in middle skilled category. Of the seven components, the highest scores lie on skills to establish and maintain a safe and secure workplace (7.87) and maintain guests' financial records (7.81). Meanwhile the lowest scores in the category sit in skills to process a financial transaction for services rendered (7.31) and manage quality customer/guest services (7.36).

TABLE 4 - THE SCORES OF FUNCTIONAL COMPETENCIES (FRONT OFFICE SUPERVISOR)

\begin{tabular}{|c|l|c|c|}
\hline $\begin{array}{c}\text { Question } \\
\text { No }\end{array}$ & $\begin{array}{c}\text { Functional Competencies } \\
\text { (front office supervisor) }\end{array}$ & $\begin{array}{c}\text { Average } \\
\text { Score }\end{array}$ & $\begin{array}{c}\text { Competency } \\
\text { level }\end{array}$ \\
\hline 15 & $\begin{array}{l}\text { Establish \& maintain a safe } \\
\text { and secure workplace }\end{array}$ & 7.87 & Skilled \\
\hline 16 & $\begin{array}{l}\text { Manage quality } \\
\text { customer/guest services }\end{array}$ & 7.36 & Skilled \\
\hline 17 & $\begin{array}{l}\text { Process a financial } \\
\text { transaction for services } \\
\text { rendered }\end{array}$ & 7.31 & Skilled \\
\hline 18 & $\begin{array}{l}\text { Maintain a paper-based filing } \\
\text { \& retrieval system }\end{array}$ & 7.50 & Skilled \\
\hline 19 & $\begin{array}{l}\text { Process transactions for } \\
\text { purchase of goods \& services }\end{array}$ & 7.48 & Skilled \\
\hline 20 & $\begin{array}{l}\text { Maintain guests' financial } \\
\text { records }\end{array}$ & 7.81 & Skilled \\
\hline 21 & $\begin{array}{l}\text { Prepare routine financial } \\
\text { statements }\end{array}$ & 7.38 & Skilled \\
\hline
\end{tabular}

With regards to the distribution level of front office supervisor's functional skills, it seems the respondents found their financial-related skills ambiguous. On the one side they are quite confident with their skill to maintain guests' financial records but on another side they are less confident with processing financial transactions for rendered services and preparing routine financial statements. This situation indicates that the respondents ' financial-related skills are unevenly developed. 


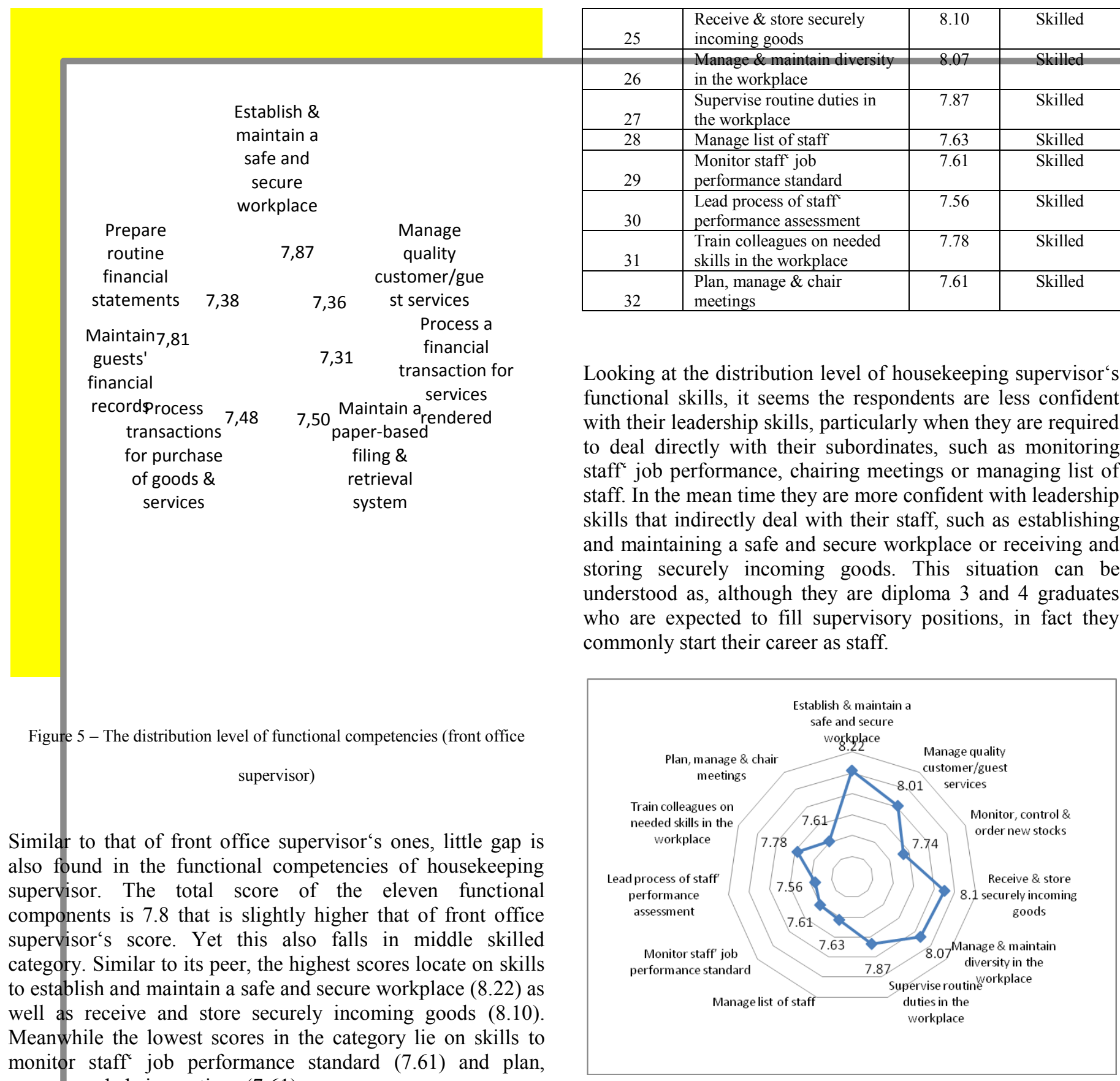
manage and chair meetings (7.61).

\section{TABLE 5 - THE SCORES OF FUNCTIONAL COMPETENCIES}

(HOUSEKEEPING SUPERVISOR)

\begin{tabular}{|c|l|c|c|}
\hline $\begin{array}{c}\text { Question } \\
\text { No }\end{array}$ & $\begin{array}{l}\text { Functional Competencies } \\
\text { (housekeeping supervisor) }\end{array}$ & $\begin{array}{c}\text { Average } \\
\text { Score }\end{array}$ & $\begin{array}{c}\text { Competency } \\
\text { level }\end{array}$ \\
\hline 22 & $\begin{array}{l}\text { Establish \& maintain a safe } \\
\text { and secure workplace }\end{array}$ & 8.22 & Skilled \\
\hline 23 & $\begin{array}{l}\text { Manage quality } \\
\text { customer/guest services }\end{array}$ & 8.01 & Skilled \\
\hline 24 & $\begin{array}{l}\text { Monitor, control \& order new } \\
\text { stocks }\end{array}$ & 7.74 & Skilled \\
\hline
\end{tabular}

Figure 6 - The distribution level of functional competencies (housekeeping supervisor)

\section{CONCLUSION AND RECOMMENDATION}

This study found little gaps between AEC competency standard and the perceived competencies of Indonesian tourism workers, particularly in the positions of front office and housekeeping supervisors. This applies not only in the core competencies but also in generic and functional ones. We argue that the low gap may be due to the majority of 
respondents are educated in the schools located in high developed, big cities. Despite having not adopted fully the regional qualification standard, these urban schools of tourism enjoy better quality of training and educators/trainers as well as relatively easier access to reputable business institutions offering internships (Interview, Hildiktipari General Secretary, 26 January 2016). The result may differ when survey undertaken in the similar schools in smaller cities.

The survey found that the respondents were less confident with the social-related skills of their competencies as well as with their direct leaderships. This situation may be of interest of educators or trainers to pay more attention to develop these aspects. Ignoring these non-technical skills may lead to reduce competitiveness advantage of the Indonesian tourism workers or professionals as they are increasingly exposed to more diverse colleagues and workplace environment.

As majority of Indonesia's schools of tourism have not yet adopted the regional competency standard in tourism (Interview, Tourism Educator, 20 November 2015 and Chairman of ASEAN Tourism Professional Monitoring Committee, 15 February 2016), the schools may seriously consider to adopt fully the ASEAN Common Competency Standards for Tourism Professionals (ACCSTP) to guarantee recognition of their skills in the regional labour market. It is also necessary for the existing Indonesian schools of tourism to become first party certification institution. As such, the certification process will be shortened, more efficient, and cover larger number of workers willing to have skill recognition.

\section{REFERENCES}

[1] ASEAN, ASEAN Economic Community Blueprint," Jakarta, ASEAN Secretariat, 2008.

[2] ASEAN, Guide to ASEAN Mutual Recognition Arrangement on Tourism Professionals - for Tourism and Hospitality Organisations," 2012.

[3] Abdurahman, S., Kesiapan Perguruan Tinggi dalam Memasuki MEA," paper read at Kesiapan Perguruan Tinggi Indonesia Menghadapi Asean Economic Community, 2015, at Jakarta.

[4] Capannelli, G., Key Issues of Labor Mobility in ASEAN," paper read at The 3rd Roundtable on Labor Migration in Asia, 23 January, 2013, at Bangkok.

[5] Gropello, E. D., Aurelien K., Prateek T., Skills for the Labor Market in Indonesia: Trends in Demand, Gaps, and Supply," The International Bank for Reconstruction and Development / The World Bank, 2011, pp. $1-10$.

[6] Hall, P. A. and Soskice, D., An introduction to Varieties of Capitalism," in Varieties of Capitalism: The institutional foundations of comparative advantage, P. A. Hall and D. Soskice (eds.), Oxford: Oxford University Press, 2001, pp. 1-70.

[7] Laksaguna, I. G. P., ASEAN MRA," paper read at Hospitality and Tourism Education Conference (HTEC), 22 May, 2013, at Kuala Lumpur.

[8] Lemy, D., Kesiapan Pendidikan Pariwisata Indonesia dalam MEA," paper read at Pre-ICBC Conference, 2015, at Jakarta.

[9] Thelen, K., Institutional change in advanced political economies," British Journal of Industrial Relations, 2009, 47(3): pp 471-498.

[10] World Bank., Indonesia Skills Report: Trend in skills demand, gaps, and suplly in Indonesia," Human Development Department - East Asia and Pacific Region, 2010. 